\title{
Controlled temperature on the microflora of fermented bottle gourd seed.
}

\author{
Ibeabuchi JC, Ogueke CC, Ahaotu N, Agunwa IM, Onuegbu NC, Okafor DC*, Alagbaso SO \\ Department of Food Science and Technology, Federal University of Technology, Owerri. P.M.B. 1526 Owerri, Imo \\ State, Nigeria
}

\begin{abstract}
Effect of controlled temperature on microflora of fermented Bottle Gourd Seeds (BGS) as well as Melon Seeds (MES) was studied. De-hulled seeds were boiled for $6 \mathrm{~h}$ and fermented at $28^{\circ} \mathrm{C}, 35^{\circ} \mathrm{C}$ and $42^{\circ} \mathrm{C}$ for $96 \mathrm{~h}$. The microbial flora of the fermented BGS and MES were determined with respects to seed type, fermentation time and fermentation temperature. The microorganisms isolated from the fermented samples included; Bacillus subtilis, Bacillus cereus, Micrococcus luteus, Staphylococcus aureus, Corynebacterium sp, and some varieties of fungi. The viable bacterial count for both the BGS and MES were within the range of $5 \times 10^{8} \mathrm{cfu} / \mathrm{g}$ and $36 \mathrm{x}$ $10^{8} \mathrm{cfu} / \mathrm{g}$ between zero and ninety-six hours. Bacillus subtilis was the major fermenting organism since it was seen at the three temperatures and throughout the fermentation period for all the samples. The absence of other fermenting organisms in some of the samples indicates that these substrates (BGS and MES) differ slightly in their ability to sustain the growth of different species of microorganisms probably due to the differences in their overall composition. The result shows that when the factors that affect the microflora of fermentation are controlled, safe good quality ogiri can be produced from BGS.
\end{abstract}

Keywords: Bottle gourd seed, Melon seed, Fermentation, Ogiri, Microflora, Controlled temperature.

Accepted on February 05, 2019

\section{Introduction}

Fermentation is one of the first methods used by man to produce and preserve food and has continued to play an important role in food processing for thousands of years. It is the breakdown of carbohydrate materials under aerobic or anaerobic conditions by the activities of microorganisms or enzymes elaborated by them (Achi 2005). It provides a way of preservation of food products and also enhances nutritive value of the food [1-4]. It aids in the destruction of undesirable substances making the food safe for consumption [5,6]. Fermentation improves digestibility, palatability and reduces the energy and time required for subsequent cooking $[7,8]$.

Most legumes that are otherwise inedible due to presence of toxicants have been found useful in the production of condiments. These fermented legume-based condiments are generally called iru by the Yorubas of the southwestern Nigeria, dawadawa among the Hausas who inhabit most of the northern part of Nigeria. Ogiriis the name used by the Igbos of the southeastern Nigeria. Owoh on the other hand, is the popular name among the Urhobos and Itsekiris in the Niger Delta region for food condiments. Similarly, okpiye is popular among the Igala and Idoma people of the Middle Belt region [9-14].

The conventional substrates for condiment production are diverse; this implies that condiments can be produced from more than one raw material. Quite often, seeds that are used for fermentation are inedible in their raw unfermented or cooked state. Available literature, reviewed shows that over nine different fermented products in Nigeria are condiments of which ogiri is one of them [15-19]. Ogiri is traditionally prepared by fermenting melon seeds (Citrullus vulgaris) [20], fluted pumpkin (Telferia occidentale) [21] or castor oil seed (Ricinus communis) [1,22,23].

Many indigenous leguminous crops including the bottle gourd (Lagenaria siceraria) are under-utilized. This is due to preference to other melon varieties, modernity and ignorance. Traditionally, the gourd is primarily used as a container for water and palm wine while the seeds and the pulp are allowed to rot and are discarded. In today's modern world, the empty gourds are also used for decorative/ornamental purposes. The seeds have not been used for nutritive or culinary purposes though they are high in nutrients [24]. It therefore becomes necessary to discover ways of utilizing this nutritious seed other than using the rind for decoration, musical instrument or bird houses. Also, ogiri is produced traditionally from spontaneous, uncontrolled fermentation of the substrate. The temperature, time, relative humidity and other fermentation variables are not strictly monitored. This results to irreproducible processes and products. As a result, product quality is usually inconsistent. Information in this area is scanty and this has made industrial production difficult. Hence, the objective of this study was to produce ogiri from bottle gourd and melon seeds at $28^{\circ} \mathrm{C}$, $35^{\circ} \mathrm{C}$, and $42^{\circ} \mathrm{C}$ respectively, to determine the viable microbial counts of the fermenting samples from $0-96 \mathrm{~h}$ of fermentation and to isolate and identify micro-organisms associated with the fermentation of both bottle gourd and melon seeds. 


\section{Materials and Methods}

\section{Material}

Sample collection: The bottle gourd seeds (Lagenaria siceraria) were collected from the retail sellers of bottle gourd rinds in Ose market in Onitsha, Anambara state Nigeria who discard the seeds, design and sell the bottles or rind for decorations and musical instruments. The discarded seeds were willingly given to us by the retail sellers since they are only interested in the rinds or bottles. The melon egusi seeds (Colocynthis citrullus lanatus) were purchased from Eke-ukwu Owerri market in Imo state, Nigeria.

Equipment: The various equipment used for this study were obtained from Department of Food Science and Technology and Department of Soil and Animal Sciences, Dr. Wesly Braide Laboratory, Nekede, Reliable Research Laboratory services, Umuahia, and Department of Zoology Laboratory, university of Jos, Nigeria.

Chemical reagents: All chemical reagents used in this experiment were of analytical grade and as prescribed by the official methods of analysis.

\section{Methodology}

\section{Preparation of 'ogiri' samples}

The traditional method of producing ogiri was used with slight modifications. Dry and healthy bottle gourd seeds (Lagenaria siceraria) were cracked, de-hulled, washed, and boiled with 3:1 w/w volume of water for six hours until they became soft. The seed (400 g) was then wrapped with tender banana leaves which were briefly passed through flame. The wrap was then boiled for another $30 \mathrm{~min}$ drying the boiling water. The sample was milled or mashed with mortar and pestle. The mashed sample was then divided into thirty portions of $10 \mathrm{~g}$ each and wrapped with the sterile plantain leaves. Ten wraps each were aseptically transferred into two different incubators preset at $35^{\circ} \mathrm{C}$ and $42^{\circ} \mathrm{C}$ respectively while third batch (10 wraps) was covered properly to avoid contamination and kept on the laboratory bench. The samples were properly labeled and fermentation was allowed to progress for ninety-six hours $(96 \mathrm{~h})$. The same procedure was followed for melon seed (Colocynthis citrullus lanatus). Samples were collected every $24 \mathrm{~h}$ for analysis. The fermented samples were dried and stored in airtight containers for subsequent analysis. The procedure is represented in Figure 1.

\section{Microbial Analysis}

\section{Cultivation and isolation of microorganisms}

Pour plate method of Jideani and Jideani was adopted [25]. Ten grams $(10 \mathrm{~g})$ of each mashed sample was weighed aseptically into $90 \mathrm{ml}$ of distilled water, agitated for $5 \mathrm{~min}$ and serially diluted up to $10^{-8}$ and $1 \mathrm{ml}$ of the $10^{-8}$ dilution was spread on already labelled nutrient agar and potato dextrose agar plates (in duplicates). The nutrient agar plates were incubated at $37^{\circ} \mathrm{C}$ for $24 \mathrm{~h}$ and $48 \mathrm{~h}$ while potato dextrose agar plates were incubated at ambient temperature $\left(28^{\circ} \mathrm{C}\right)$ for at least $72 \mathrm{~h}$. Un-inoculated plates were also incubated for reference. After the incubation periods the plates were examined and both bacterial and fungal counts were taken from the countable plates. The nutrient agar

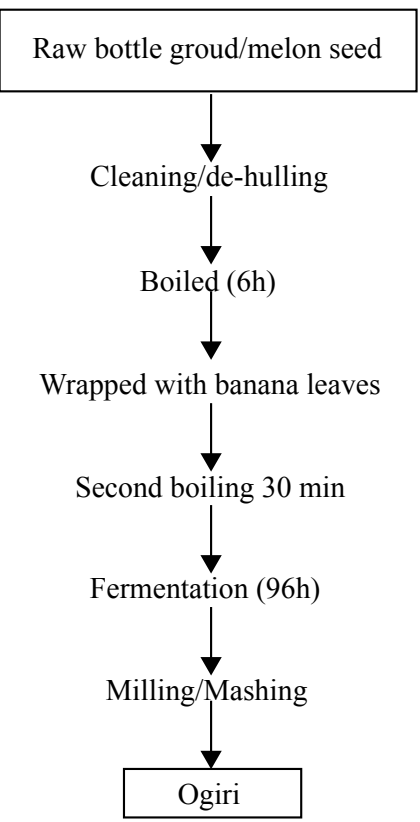

Figure 1. Production of 'ogiri' using bottle gourd and melon seed.

was used for cultivation of heterotrophic bacteria, and potato dextrose agar for fungi growth.

\section{Observations}

The dilution plates for bacteria were examined after $48 \mathrm{~h}$ and the number of colonies on each plate counted and recorded. The colony characterisation for the fungal isolates were noted and further identified by microscopic observation of their wet mounts using lactophenol cotton blue. The $\mathrm{pH}$ and \%TTA (Titratable Acidity) of the fermenting samples were recorded for each sampling day.

\section{Isolation of pure cultures}

After incubation, the plates were examined and discrete colonies picked, sub-cultured and put in a slope. Each slope culture was re-streaked on nutrient agar to ensure purity. Each pure culture was then inoculated onto sterile nutrient agar slants in screw capped MacCartney bottles. These were incubated at $37^{\circ} \mathrm{C}$ for $24 \mathrm{~h}$ and preserved in the refrigerator at $4^{\circ} \mathrm{C}$ as stock cultures for further tests. The pure bacterial cultures were appropriately labelled as A-E. Pure fungal cultures were made by transferring a portion of the growing spores or edge of the colony on a sterile potato dextrose agar plate and incubating at ambient temperature.

\section{Characterisation of bacterial isolates}

Purified colonies were identified first by gram staining, then by biochemical reactions and sugar fermentation tests. Colonial morphology and microscopic characteristics were noted and recorded. Further characterisation and identification of bacterial isolates were based on biochemical reactions (catalase, oxidase, coagulase, Indole, citrate tests) and sugar fermentations as described by Buchanan and Gibbson [26].

\section{Results and Discussion}

\section{Results}

The result in Tables 1-4 shows the viable bacterial counts, 
Table 1. Viable bacterial count of fermenting bottle gourd seed using nutrient agar.

\begin{tabular}{|c|c|c|c|c|c|c|}
\hline \multicolumn{7}{|c|}{ Viable bacterial count (cfu/g) } \\
\hline S/No & Seed type & Time (h) & $28^{\circ} \mathrm{C}$ & $35^{\circ} \mathrm{C}$ & $42^{\circ} \mathrm{C}$ & Mean \\
\hline 1 & BGS & 0 & $5 \times 10^{8}$ & $5 \times 10^{8}$ & $5 \times 10^{8}$ & $5 \times 10^{8}$ \\
\hline 2 & BGS & 24 & $9 \times 10^{8}$ & $13 \times 10^{9}$ & $10 \times 10^{8}$ & $10.67 \times 10^{8}$ \\
\hline 3 & BGS & 48 & $11 \times 10^{8}$ & $17 \times 10^{8}$ & $12 \times 10^{8}$ & $13.33 \times 10^{8}$ \\
\hline 4 & BGS & 72 & $26 \times 10^{8}$ & $27 \times 10^{8}$ & $24 \times 10^{8}$ & $25.67 \times 10^{8}$ \\
\hline 5 & BGS & 96 & $36 \times 10^{8}$ & $24 \times 10^{8}$ & $23 \times 10^{8}$ & $27.67 \times 10^{8}$ \\
\hline Mean & & & $17.4 \times 10^{8}$ & $17.2 \times 10^{8}$ & $15.8 \times 10^{8}$ & \\
\hline 1 & MES & 0 & nil & nil & nil & \\
\hline 2 & MES & 24 & $6 \times 10^{8}$ & $8 \times 10^{8}$ & $5 \times 10^{8}$ & $6.33 \times 10^{8}$ \\
\hline 3 & MES & 48 & $8 \times 10^{8}$ & $13 \times 10^{8}$ & $9 \times 10^{8}$ & $10 \times 10^{8}$ \\
\hline 4 & MES & 72 & $20 \times 10^{8}$ & $20 \times 10^{8}$ & $16 \times 10^{8}$ & $18.67 \times 10^{8}$ \\
\hline 5 & MES & 96 & $27 \times 10^{8}$ & $21 \times 10^{8}$ & $16 \times 10^{8}$ & $21.33 \times 10^{8}$ \\
\hline Mean & & & $13.3 \times 10^{8}$ & $15.5 \times 10^{8}$ & $11.5 \times 10^{8}$ & \\
\hline
\end{tabular}

Table 2. Colonial, microscopy and morphological characteristics of bacterial isolates on nutrient agar.

\begin{tabular}{|c|c|c|c|c|}
\hline \multirow[t]{2}{*}{ Isolate } & \multirow[t]{2}{*}{ Morphological characteristics } & \multicolumn{2}{|c|}{ Microscopy } & \multirow[t]{2}{*}{ Probable Identity of microorganism } \\
\hline & & Spore & Gram & \\
\hline A & $\begin{array}{l}\text { Straight rods in short chains with oval central spores, dull and dry } \\
\text { irregular flat cream colonies }\end{array}$ & + & $+\mathrm{R}$ & Bacillus sp \\
\hline B. & Cocci in pairs, tetrad or irregular clusters, small round yellow colonies & - & $+S$ & Micrococcus sp \\
\hline C & $\begin{array}{l}\text { Straight or slightly curved rods with tapered end circular umbonate } \\
\text { cream colonies }\end{array}$ & - & $+\mathrm{R}$ & Corynebacterium sp \\
\hline D & $\begin{array}{l}\text { Straight rods in short chains with oval central spores, mucoid and slimy } \\
\text { irregular raised colonies }\end{array}$ & + & $+\mathrm{R}$ & Bacillus sp \\
\hline $\mathrm{E}$ & Spherical cells (cocci) in clusters, few in pairs or tetrads & - & $+S$ & Staphylococcus sp \\
\hline
\end{tabular}

KEY: S: Spherical; R: Rod; +: Positive; -: Negative.

Table 3. Biochemical test and sugar utilization of bacterial isolates.

\begin{tabular}{|c|c|c|c|c|c|c|c|c|c|c|c|c|c|c|c|}
\hline \multicolumn{10}{|c|}{ Biochemical test } & \multicolumn{5}{|c|}{ Sugar Utilization } & \multirow{2}{*}{$\begin{array}{l}\text { Probable Identity of } \\
\text { microorganisms }\end{array}$} \\
\hline Isolate & Cat & Oxi & Coag & In & MR & VP & Cit & $\mathrm{NO}_{3}$ & Urease & Glu & Suc & Mal & Lac & Mann & \\
\hline A & + & - & - & - & - & + & + & + & - & + & - & - & $+\mathrm{s}$ & + & Bacillus subtils \\
\hline B & + & - & - & - & + & - & + & - & + & - & - & - & - & - & Micrococcus luteus \\
\hline C & + & - & + & - & - & + & + & + & + & + & - & + & - & - & Corynebacterium sp \\
\hline $\mathrm{D}$ & + & - & - & - & - & + & + & + & - & + & - & - & $+s$ & - & Bacillus cereus \\
\hline$E+$ & - & + & - & - & - & + & - & + & - & + & + & + & + & + & Staphylococcus aureus \\
\hline
\end{tabular}

microorganisms identified during BGS and MES fermentation as affected by seed type, fermentation time, and temperature of fermentation.

\section{Discussion}

Microorganisms identified during BGS and MES fermentation as affected by seed type: The result in Table 1 showed the Viable Bacterial Counts (VBC) in the fermenting bottle gourd and melon seeds. The Melon Seed (MES) showed no bacterial growth at zero hour while the Bottle Gourd Seeds (BGS) sample had a viable bacterial count (VBC) of $5 \times 10^{8}$ at zero hour. This could suggest that the spores of the inherent microorganisms in BGS survived the heat treatment of boiling. The inherent microorganisms in MES could be mostly vegetative cells which were readily destroyed during boiling. The bacterial count remained generally higher in BGS than MES samples throughout the period of fermentation.

The VBC for both the BGS and MES which were within the range of $5 \times 10^{8} \mathrm{cfu} / \mathrm{g}$ and $36 \times 10^{8} \mathrm{cfu} / \mathrm{g}$ between zero and ninety-six hours falls within the range of values reported by most authors. Aminat and Esiobu (2014) reported similar viable bacterial counts $(\mathrm{VBC})$ of $120-163 \times 10^{7} \mathrm{cfu} / \mathrm{g}$ within three days of fermentation of Parkia biglobosa. Akinyele and Oloruntoba reported a VBC of $87-91 \times 10^{7} \mathrm{cfu} / \mathrm{g}$ for Cucumeropsis manni after $72 \mathrm{~h}$ fermentation [27].

Similar microorganisms were found in both fermented BGS and MES. They were gram positive rods and cocci and included Bacillus subtilis, Bacillus cereus, Micrococcus luteus, Staphylococcus aureus, Corynebacterium sp. Other organisms identified were the following yeast and moulds: Saccharomyces sp, Rhizopus sp, and Penicilium sp. Results in Table 2 showed the colonial, microscopy, and morphological characteristics of bacterial isolates identified during fermentation of both Bottle Gourd Seeds (BGS) and Melon Seeds (MES) while the biochemical and sugar fermentation tests were shown in Table 3. Previous authors have also reported the prevalence of such microorganisms during production of condiments from legumes. Mbajunwa et al. [28] and Obeta [29] isolated Staphylococcus saprophyticus, Bacillus pumilus, Bacillus subtilis and Bacillus licheniformis in fermenting ugba samples. Ogunshe et al. [30] observed that Bacillus species occurred most consistently and predominated the fermentation of Albizia saman into aisa (a condiment), with the production of the highest ammonia-like aroma, characteristic of leguminous-based fermented condiments. 
Citation: Ibeabuchi JC, Ogueke CC, Ahaotu N, et al. Controlled temperature on the microflora of fermented bottle gourd seed. J Food Sci Nutr.

Table 4. Bacterial isolates from the melon and bottle gourd sample at different temperature of fermentation.

\begin{tabular}{|c|c|c|c|c|c|}
\hline S.no & Isolate Sample code & Fermentation Time (h) & $28^{\circ} \mathrm{C}$ & $35^{\circ} \mathrm{C}$ & $42^{\circ} \mathrm{C}$ \\
\hline 1 & BGS & 0 & Bacillus subtilis & Bacillus subtilis & Bacillus subtilis \\
\hline \multirow[t]{2}{*}{2} & \multirow[t]{2}{*}{ BGS } & \multirow[t]{2}{*}{24} & Bacillus subtilis & Bacillus subtilis & Bacillus subtilis \\
\hline & & & & Staphylococcus aureus & \\
\hline \multirow[t]{3}{*}{3} & \multirow[t]{3}{*}{ BGS } & \multirow[t]{3}{*}{48} & Bacillus subtilis & Bacillus cereus & Bacillus subtilis \\
\hline & & & Bacillus subtilis & Bacillus cereus & Staphylococcus aureus \\
\hline & & & Micrococcus luteus & Staphylococcus aureus & \\
\hline \multirow[t]{3}{*}{4} & \multirow[t]{3}{*}{ BGS } & \multirow[t]{3}{*}{72} & Bacillus subtilis & Bacillus subtilis & Bacillus subtilis \\
\hline & & & Bacillus cereus & Bacillus subtilis & Bacillus cereus \\
\hline & & & Micrococcus luteus & Rhizopus sp & Penicillium sp \\
\hline \multirow[t]{3}{*}{5} & \multirow[t]{3}{*}{ BGS } & \multirow[t]{3}{*}{96} & Bacillus subtilis & Bacillus subtilis & Saccharomyces sp \\
\hline & & & Bacillus cereus & Bacillus subtilis & \\
\hline & & & Rhizopus sp & & \\
\hline 6 & MES & 0 & No growth & No growth & No growth \\
\hline 7 & MES & 24 & Bacillus subitilis & Bacillus subitilis & Bacillus subitilis \\
\hline \multirow[t]{3}{*}{8} & \multirow[t]{3}{*}{ MES } & \multirow[t]{3}{*}{48} & Bacillus subtilis & Bacillus subtilis & Saccharomyces sp \\
\hline & & & Bacillus cereus & Bacillus cereus & Bacillus subtilis \\
\hline & & & Penicillium sp & & \\
\hline \multirow[t]{3}{*}{9} & \multirow[t]{3}{*}{ MES } & \multirow[t]{3}{*}{72} & Bacillus sutilis & Bacillus subtilis & Corynebacteriumsp \\
\hline & & & Bacillus cereus & Bacillus cereus & Bacillus subtilis \\
\hline & & & Micrococcus luteus & Rhizopus sp & \\
\hline \multirow[t]{3}{*}{10} & \multirow[t]{3}{*}{ MES } & \multirow[t]{3}{*}{96} & Conyrebacberium sp & Corynebacterium & Bacillus subtilis \\
\hline & & & Bacillus subtilis & Bacillus subtilis & Corynebaterium sp \\
\hline & & & Micrococcus luteus & Bacillus cereus & Saccharomyces sp \\
\hline
\end{tabular}

However, Staphylococcus aureus was found only in the BGS samples but were not present in MES. On the other hand, Corynebacterium sp was only found in some of the MES samples. This suggests that the substrates (BGS and MES mash) were slightly different in their ability to sustain the growth of different species of microorganisms probably due to the differences in their overall composition.

Microorganisms identified during fermentation as affected by fermentation time: The results in Table 1 showed that there was a general trend of increase in Viable Bacterial Count (VBC) for all the fermenting samples. The mean value of $\mathrm{VBC}$ increased from $5 \times 10^{8} \mathrm{cfu} / \mathrm{g}$ at $0 \mathrm{~h}$ to $27.67 \times 10^{8} \mathrm{cfu} / \mathrm{g}$ at $96 \mathrm{~h}$ for BGS. The VBC increased from $0 \mathrm{cfu} / \mathrm{g}$ at $0 \mathrm{~h}$ fermentation to a mean value of $21.33 \times 10^{8} \mathrm{cfu} / \mathrm{g}$ after $96 \mathrm{~h}$ for the MES samples. A similar trend had been noted by Aminat and Esiobu [31] who reported similar viable bacterial counts of $120-163 \times 10^{7} \mathrm{cfu} / \mathrm{g}$ within three days of fermentation of Parkia biglobosa. Akinyele and Oloruntoba [27] reported $8.7 \times 10^{6} \mathrm{cfu} / \mathrm{g}-9.1 \times 10^{6} \mathrm{cfu} / \mathrm{g}$ for fermented Cucumeropsis mannii. This can be explained by the fact that the medium is rich in nutrients which enabled the microorganisms to multiply within the fermenting mash.

Bacillus subtilis was identified in all the stages of the fermentation from 24-48 $\mathrm{h}$ for BGS and MES samples (Table 4). Staphylococcus aureus was observed in some BGS samples after $24 \mathrm{~h}$ and $48 \mathrm{~h}$ but were absent in the $96 \mathrm{~h}$ samples. The reduction in the population of Staphylococcus aureus is in agreement with the observation of Babalola and Oluwamodupe [32], that the microbial isolate, Bacillus sp, was the major observable fermenting microorganism, and posses' antimicrobial activities against Escherichia coli, Staphylococcus aureus, Proteus spand Pseudomonas aeruginosa.

The fungi Rhizopus sp, penicilium and Sacharomyces sp were identified after $72 \mathrm{~h}$ and $96 \mathrm{~h}$ of fermentation. These may have contributed to the flavor development.

Some workers have identified different microorganisms in fermented melon seeds. These include Bacillus sp, E. coli, Proteus sp, Pediococcus sp and Alcaligenes sp [3,11,33]. However, Bacillus subtilis and B. licheniformis were identified as the main bacteria involved in the fermentation of melon seed because of their ability to produce the requisite enzymes for the breakdown of proteins and production of the various flavor compounds associated with ogiri egusi $[3,34]$.

Microorganisms identified during fermentation as affected by temperature of fermentation: The viable bacterial count was fewer in both the Bottle Gourd (BGS) and Melon Seed (MES) samples fermented at $42^{\circ} \mathrm{C}$. As fermentation temperature increased from $28^{\circ} \mathrm{C}$ to $42^{\circ} \mathrm{C}$, the mean $\mathrm{VBC}$ values decreased from $17.4 \times 10^{8} \mathrm{cfu} / \mathrm{g}$ to $15.8 \times 10^{8} \mathrm{cfu} / \mathrm{g}$ for BGS and $15.38 \times 10^{8}$ $\mathrm{cfu} / \mathrm{g}$ to $11.5 \times 10^{8} \mathrm{cfu} / \mathrm{g}$ for the MES (Table 1 ). It was also observed that for samples fermented at $35^{\circ} \mathrm{C}$ and $42^{\circ} \mathrm{C}$, the VBC only increased up to $72 \mathrm{~h}$ and decreased afterwards. This corresponded with the increase in protease activity which increased within $48-72 \mathrm{~h}$ of fermentation and reduced thereafter especially for samples fermented at $35^{\circ} \mathrm{C}$ and $42^{\circ} \mathrm{C}$ (Table 1). The decline in microbial population may be attributed to the faster accumulation of toxic compounds and metabolites at higher fermentation temperature. This may be inhibitive to some microorganisms [35,36].

Bacillus subtilis occurred at all the fermentation temperatures, and throughout the period of fermentation. Carpenter [37] reported that Bacillus subtilis may grow within the temperature range of $8^{\circ} \mathrm{C}$ to $55^{\circ} \mathrm{C}$ with its optimum at $28^{\circ} \mathrm{C}$ to $40^{\circ} \mathrm{C}$. This may account for their growth in all the samples irrespective of the temperature. Another reason could be because Bacillus species are spore formers therefore could survive high temperatures. 
Micrococcus luteus was only isolated from samples fermented at $28^{\circ} \mathrm{C}$ and did not occur in samples fermented at $35^{\circ} \mathrm{C}$ and $42^{\circ} \mathrm{C}$. This is in agreement with Carpenter [37] who reported $25^{\circ} \mathrm{C}$ to $30^{\circ} \mathrm{C}$ as the optimum temperature for its growth. Staphylococcus aureus as well as Saccharomyces sp were only isolated from samples fermented at $35^{\circ} \mathrm{C}$ and $42^{\circ} \mathrm{C}$. Optimum temperature for the growth of Staphylococcus aureus has also been reported as $35^{\circ} \mathrm{C}$ to $40^{\circ} \mathrm{C}$ [37].

Bacillus cereus was identified in some of the samples, although, it was absent in the samples fermented at $42^{\circ} \mathrm{C}$ for $96 \mathrm{~h}$. The presence of this microorganism poses some health concern since it produces enterotoxins [31]. Aminat and Esiobu reported that the presence of Bacillus cereus, which is capable of secreting enterotoxins in these fermented condiment may indeed constitute a health hazard by possibly causing flatulence and diarrhea disease in some individuals [31]. However, a safe practice would be to ferment at a higher temperature $\left(42^{\circ} \mathrm{C}\right)$ for a long time $(96 \mathrm{~h})$ and to heat the condiment before consumption.

It can also be observed that the first $72 \mathrm{~h}$ could be assumed to be the most active period for all the fermentation temperatures $\left(28^{\circ} \mathrm{C}, 35^{\circ} \mathrm{C}\right.$ and $\left.42^{\circ} \mathrm{C}\right)$. It is the period of exponential growth [29-41]. It is therefore possible that fermentation for the rest of the process was sustained more by the enzymes already produced than by the bacterial population [38]. Njoku and Okemadu in their study of ugba fermentation observed that alpha amylase; proteolytic and lipolytic enzymes were detectable at the start of fermentation and attained their maximum levels at 24-36 $\mathrm{h}$ fermentation [42]. Bacillus species have been reported as producers of enzymes such as amylase, galactanase, galactosidase, and glucosidase which are involved in the degradation of carbohydrates $[43,44]$. Amylase hydrolyses carbohydrates into sugar. Similarly, galactanase softens the texture of the seeds and liberates sugar for digestion. Most legumes contain large amounts of non-digestible carbohydrate which may include arabinose, starchyose, sucrose and raffinose [38]. These carbohydratess are associated with abdominal distention and flatulence in human [45-47]. But fermentation was found to reduce total flatulent factors (oligosaccharides) from 16.5 to $2.0 \mathrm{mg} / \mathrm{g}$ in soy beans [48] and from 0.16 to 0.1 $\mathrm{mg} / \mathrm{g}$ in groundnut [49].

The significant biochemical changes in most fermented high protein product, protein synthesis and hydrolysis are important factors responsible for changes in textures and flavour [50]. Soluble low molecular weight peptides and amino acids contribute to flavour and are produced through the enzymatic breakdown of proteins [51,52].

\section{Conclusion}

The findings from this work have shown that the micro flora as well as the microbial load of fermented BGS and MES are greatly influenced by the seed type, fermentation time and fermentation temperature. It was also noted that the presence of flavour enhancing fungi and enterotoxin secreting bacteria was a function of fermentation time and fermentation temperature respectively. The microflora during the fermentation of fermented food products affect the food quality of the final product as it gives it its peculiar physical properties. Therefore, controlling these factors that affect the microflora of fermented BGS and MES will help in the production of safe, good quality ogiri.

\section{References}

1. Odunfa SA. Microbiological and toxicological aspect of fermentation of castor oil seeds for ogiri production. J Food Sci. 1985b;50:1758-9.

2. Reddy NR, Pierson MD. Reduction in anti-nutritional and toxic components in plant foods by fermentation. Foods Research International. 1999;281-90.

3. Barimalaa IS, Achinewhu SC, Yibatima I, et al. Studies on the solid state fermentation of Bambara Groundnut (Vigna subterranean L.). J Sci Food Agric. 1989;66:443-51.

4. Achi OK, Okereka EG. Proximate composition and functional properties of Prosopis africana seed flour. Journal of Managment Technology. 1999;1:7-13

5. Fetuga BL, Babatunde GM, Onyenuga VA. Protein quality of some Nigerian food stuffs. Chemical assay of nutrients and amino acid composition. J Sci Food Agric. 1973;24:5051514.

6. Eka OU. Effect of fermentation on the nutrient status of locust beans. Food Chem. 1980;5:305-8.

7. Steinkraus KH. Potential of African fermented foods IFS/ UNU workshop on Development of indigenous fermented foods and food technology in Africa. Dovala, Cameroun Oct. 1985.

8. Ojo MO. The role of agro-industries in promoting a food culture in Nigeria. Central Bank of Nigeria Economy and Financial Review. 1991;29:306-14.

9. Sanni AI, Ogbonna DN. The production of owoh-a Nigerian fermented seasoning agent from cotton seed (Gossypium hirsitium). Food Microbiol. 1991;8:223-229.

10. Sanni AI, Ogbonna DN. Biochemical studies on owoh-a Nigerian fermented soup condiment from cotton seed. Food Microbiol. 1992;9:177-83.

11. Sanni AI, Onilude A, Fadahunsi I, et al. Selection of starter cultures for the production of ugba, a fermented soup condiment. Eur Food Res Technol. 2000;215(2):176-180.

12. Achi OK. Microorganisms associated with natural fermentation of Prosopis africana seeds production of Okpiye Plant foods. Human Nutrition. 1992;42:297-304.

13. Odibo FJC, Ugwu DA, Ekeoha DC. Microorganisms associated with the fermentation of Prosopis seeds for ogiriokpei production. J Food Sci Tech. 1992;29:306-7.

14. Sanni AI. Biochemical changes during the production of okpehe a Nigerian fermented soup condiment. Lebenson Wiss Technol. 1993;15:97-100.

15. Achi OK. Traditional fermented protein condiments in Nigeria. Afr J Biotechnol. 2005;4(13):1612-21.

16. Odunfa SA. A note on the microorganisms associated with 
Citation: Ibeabuchi JC, Ogueke CC, Ahaotu N, et al. Controlled temperature on the microflora of fermented bottle gourd seed. J Food Sci Nutr. 2019;2(1):8-14.

the fermentation of African locust bean (Parkiafilicoidea) during iru production. J Plant Foods. 1981a;3:245-50.

17. Antai SP, Ibrahim MH. Microorganisms associated with African bean (Parkia filcoidea WelW). Fermentation for dawadawa production. J Appl Bacteriol. 1986;61:145-8.

18. Popoola TOS, Akueshi CO. Microorganism associated with the fermentation of soybean daddawa (a condiment) Nig Food J. 1984;2:194-6.

19. Ogbadu CO, Okagbue RN. Bacterial fermentation of soybeans for daddawa production. J Appl Bacteriol. 1988;65:353-6.

20. Odunfa SA. Microbiology and amino acid composition of 'ogiri, a food condiment from fermented melon seeds. Nahrung banner. 1981b;25:811-6.

21. Odibo FJC, Umeh AI. Microbiology of the fermentation of Telfera seeds for ogiri production. J Appl Microbiol Biotechnol. 1989;5:217-22.

22. Anosike EO, Egwuatu CK. Biochemical changes during the fermentation of castor oil (Ricinus communis) seeds for use as a seasoning agent. Plant Foods Hum Nutr. 1981;30:181-4.

23. Barber LI, Achinewhu SC, Ibiama E. The Microbiology of ogiri production from castor seeds (Ricinus communis). Food Microbiol. 1988;5:10:177-83.

24. Christian A. Studies of selected physiochemical propertiesof fluted pumpkin (Telfairia occidentalis hook F.) seed oil and tropical almond (Terminalia catappia L.) seed oil gatemor. Pak J Nutr. 2006;5(4):304-7.

25. Jideani VA, Jideani IA. Laboratory Manual of Food Bacteriology. Amana Printing and Advertising Ltd. 2006;31-160.

26. Buchanan RE, Gibbons NE. Bergey's manual of Determinative Bacteriology (8th ed.). Williams and Wilkins Comp. Baltimore, U.S.A. 1974.

27. Akinyele BJ, Oloruntoba OS. Comparative Studies on Citrullus vulgaris, Citrullus colocynthis and Cucumeropsis mannii for Ogiri Production. J Mycol Res. 2013;3(1):1-18.

28. Mbajunwa OK, Akingbala JO, Mutongoy K, et al. Starter culture evaluation for the production of ugba from African oil bean seed (Pentaclethra macrophylla). J Sci Food Agri. 1998;77:127-132.

29. Obeta JAN. A note on the microorganisms associated with the fermentation of seeds of African oil bean seed (Pentaclaenthra macrophylla). J Appl Bacteriol. 1983;54:433-5.

30. Ogunshe AAO, Omotosho MO, Ayansina ADV. Microbial studies and biochemical characteristics of controlled fermented afiyo-a Nigerian fermented food condiment from Prosopis africana (Guill and Perr) Taub. Pak J Nutr. 2007;6(6):620-7.

31. Aminat OA, Esiobu N. Bacterial succession studies during fermentation of Parkia biglobosa to iru using molecular methods. Br Biotechnol J. 2014;2(1):49-59.
32. Babalola RO, Oluwamodupe EG. Effect of fermentation on nutritional and anti-nutritional properties of fermenting Soy beans and the antagonistic effect of the fermenting organism on selected pathogens. Microbiol Res J Int. 2012;3(10):3338

33. Barber LI, Achinewhu SC. Microbiology of ogiri production from melon seeds (Citrullus vulgaris). Nig Food J. 1992;10:129-35.

34. Nwosu CD, Ojimelukwe PC. Improvement of the traditional method of ogiri production and identifications of the microorganisms associated with the fermentation process. J Appl Microbiol. 2000;94(3):381-91.

35. David OM, Aderibigbe EY. Microbiology and Proximate Composition of 'Ogiri', A Pastry Produced from Different Melon Seeds. New York Science Journal. 2010;3(4):18-27.

36. Yong FM, Wood BJB. Biochemical changes in experimental soysauce koji. J Food Tech. 1977;12:163-17.

37. Carpenter PL. Effects of the environment on bacteria. Saunders company, University press, Washington square, Philadephia. 1977;233-46.

38. Odunfa SA, Oyeyiola GF. Microbiological study of the fermentation of ugba-a Nigerian indigenous fermented food flavour. J Plant Foods. 1985;6:155-63.

39. Sarkar PK, Cook PE, Owens JD. Bacillus licheniformis of soybeans. World J Microbiol Biotechnol. 1993;9:295-9.

40. Folarin A, Oluwajenyo MO. Incidence and characterization of Bacillus cereus isolated from traditional fermented meals in Nigeria. J Food Prot. 2004;67(12): 2805-8.

41. Asagbara A, Oyewole OB. Fermentation studies on carrot juice processed to table wine. Nig Food. 2002;30:74-8.

42. Njoku HO, Okemadu CP. Biochemical changes during the natural fermentation of the African oil bean for the production of ugba. J Sci Food Agri. 1989;49:457-65.

43. Omafuvbe BO, Shonukan OO, Abiose SH. Microbiological and biochemical changes in the tradition fermentation of soybean for soy-daddawa -a Nigerian food condiment. Food Microbiol. 2000;17:469-74.

44. Kriers JL, Vanlaekan AEA, Rombouts FM, et al. In vitro digestibility of Bacillus fermented soyabean. Int Food Microbiol. 2000;60:163-9.

45. Sarkar PK, Jonnes L, Craven GS, et al. (1997) Oligosacharide profiles of soybeans during kinema production. Appl Microbiol. 24:337-339.

46. Naczk M, Amarowicz R, Shashidi. A-Galactosidase of sucrose in Foods: Composition, Flatulence-causing effect and removal. ACS Symposium Series. 1997;662:127-51.

47. Achinewhu SC. The effect of fermentation on carbohydrate and fatty acid composition of African oil bean seed (Pentaclethra macrophylla). Food Chem. 1986;19:105-116.

48. Reddy NR, Pierson MD, Salunkhe DK. Legume-based fermented foods. Boca Raton CRC press. 1986;95-117. 
49. Fardiaz D, Markakis P. Degradation of phytic acid in oncom (fermented peanuts press cake). J Food Sci. 1981;46:523-5.

50. Whitaker JR. Biochemical changes during the fermentation of high protein foods. J Food Tech. 1986;32:175-90.

51. Ouoba LII, Rechinger KB, Barkholt V, et al. Degradation of proteins during the fermentation of African locust bean (Parkia biglobosa) by strain of Bacillus subtilis and Bacillus pumilus for production of soumbala. J Appl Microbiol. 2003;94:396-402.
52. Odunfa SA. Biochemical changes in fermenting African locust bean (Parkia biglobosa) during iru fermentation. J Food Tech. 1985a;20:295-303.

\section{${ }^{*}$ Correspondence to:}

Okafor DC

Department of Food Science and Technology

Federal University of Technology

Owerri. P.M.B. 1526 Owerri, Imo State

Nigeria

Tel: +2348037837771

E-mail: okafordamaris@gmail.com 